Canadian University Music Review

Revue de musique des universités canadiennes

\title{
Editorial Éditorial
}

\section{Alan M. Gillmor et Jean-Jacques Nattiez}

Numéro 1, 1980

URI : https://id.erudit.org/iderudit/1013730ar

DOI : https://doi.org/10.7202/1013730ar

Aller au sommaire du numéro

Éditeur(s)

Canadian University Music Society / Société de musique des universités

canadiennes

ISSN

0710-0353 (imprimé)

2291-2436 (numérique)

Découvrir la revue

Citer ce document

Gillmor, A. M. \& Nattiez, J.-J. (1980). Editorial / Éditorial. Canadian University Music Review / Revue de musique des universités canadiennes, (1), vii-x. https://doi.org/10.7202/1013730ar

All Rights Reserved (C Canadian University Music Society / Société de musique des universités canadiennes, 1980
Ce document est protégé par la loi sur le droit d'auteur. L'utilisation des services d’Érudit (y compris la reproduction) est assujettie à sa politique d'utilisation que vous pouvez consulter en ligne.

https://apropos.erudit.org/fr/usagers/politique-dutilisation/ 


\section{EDITORIAL}

We are pleased to present the first issue of the Canadian University Music Review, which supercedes the CAUSM/ ACEUM Journal as the official journal of the Canadian University Music Society. We trust that our members and readers will be favorably impressed with the new format and improved appearance of the publication, a new image which we dare suggest might be construed as a symbol of the growing strength and vitality of the Society as it begins the second decade of its existence.

Although we shall continue to publish the best Canadian scholarship in all areas of musical research, we shall also solicit contributions from the international musical community in the firm belief that parochialism and protectionism are neither necessary nor desirable. Nevertheless, the Review must and will continue to serve the membership of the Society first and foremost, and in this regard it is encouraging to note that the contributions to this first issue of the new series represent scholarly activity in nearly every major geographical region of the country.

The French-language section of this issue is devoted exclusively to ethnomusicology. While this reflects the recent development of this particular discipline in Quebec, it is obvious that it is not the intention of the editorial board, in the future, to give preference to any specific field or topic within an area of musicology; the second issue, already in preparation, will make this clear. In any event, the general policy we intend to follow is to afford students and part-time personnel the same opportunities provided those holding professorial appointments, the sole criterion being quality. The articles by Berthiaume-Zavada, Dauphin, and Esses are witness to this policy.

It is our intention to reflect musicological activity in Canada in all its variety. In this regard, we are particularly gratified by the contribution of a Japanese colleague, Yoshihiko Tokumaru. Already well known in his native country, he has 
spent two years in Montreal as a visiting scholar and teacher. His article offers a new theory of shamisen music supported by first-hand documentation unavailable in any other major Western language.

Finally, we would like to note our pleasure in initiating this first issue of the Review with two articles (Clarke and Hardwick) on the work of Healey Willan (1880-1968) - our modest offering to the centenary celebration of an acknowledged grand man of Canadian music, whose significant contribution to the quality of musical life in this country is an indisputable part of the historical record.

A.M.G. J.-J.N. 


\section{ÉDITORIAL}

Nous avons le plaisir de présenter le premier numéro de la Revue de musique des universités canadiennes, qui remplace le CAUSM/ACEUM Journal en tant qu'organe officiel de la Société de musique des universités canadiennes. Nous osons croire que nos membres et nos lecteurs seront favorablement impressionnés par la nouvelle présentation de la revue, et que celle-ci, en retour, reflétera la vigueur croissante et le dynamisme de notre Société au moment où elle s'engage dans sa seconde décennie.

Alors que nous continuerons de publier les meilleurs travaux scientifiques d'origine canadienne dans tous les domaines de la recherche musicale, nous ferons également appel à la collaboration de la communauté musicale internationale, fermement convaincus en cela que l'esprit de clocher et le protectionnisme ne sont ni indiqués ni souhaitables. Néanmoins, la Revue se doit de continuer à servir d'abord et avant tout les membres de la Société, et elle restera fidèle à ce principe. À cet égard, il est encourageant de noter que ce premier numéro de la nouvelle série présente des textes de collaborateurs recrutés dans presque toutes les grandes régions géographiques du pays.

La partie française du présent numéro est entièrement consacrée à l'ethnomusicologie pour souligner le récent développement de cette discipline au Québec. Il est clair, cependant, que le comité de rédaction n'entend pas, dans l'avenir, privilégier une branche ou un sujet particuliers de la musicologie; le second numéro, déjà en préparation, en fera la preuve. À tout événement, la politique générale que nous entendons suivre consiste à donner aux étudiants et chargés de cours la même place qu'aux professeurs dits de carrière, notre seul critère étant celui de la qualité. Les articles de BerthiaumeZavada, Dauphin et Esses sont les garants de cette politique.

Désireux de refléter toutes les facettes de l'activité musicologique au Canada, nous sommes particulièrement 
heureux de compter parmi nos collaborateurs un collègue japonais, Yoshihiko Tokumaru, qui, déjà bien connu dans son pays, a passé deux ans à Montréal comme chercheur et professeur invité. Il nous livre ici, en français, une nouvelle théorie de la musique de syamisen, appuyée sur une documentation de première main, inaccessible dans aucune des grandes langues occidentales.

En dernier lieu, nous voulons souligner le plaisir que nous éprouvons à lancer ce premier numéro de la Revue au moyen de deux articles (Clarke et Hardwick) consacrés à l'ouvre de Healey Willan (1880-1968). Ceux-ci constituent notre modeste apport à la célébration du centenaire de cette grande figure de la musique canadienne, dont la contribution remarquable à la qualité de la vie musicale en ce pays est déjà inscrite dans l'histoire.

A.M.G. J.-J.N. 